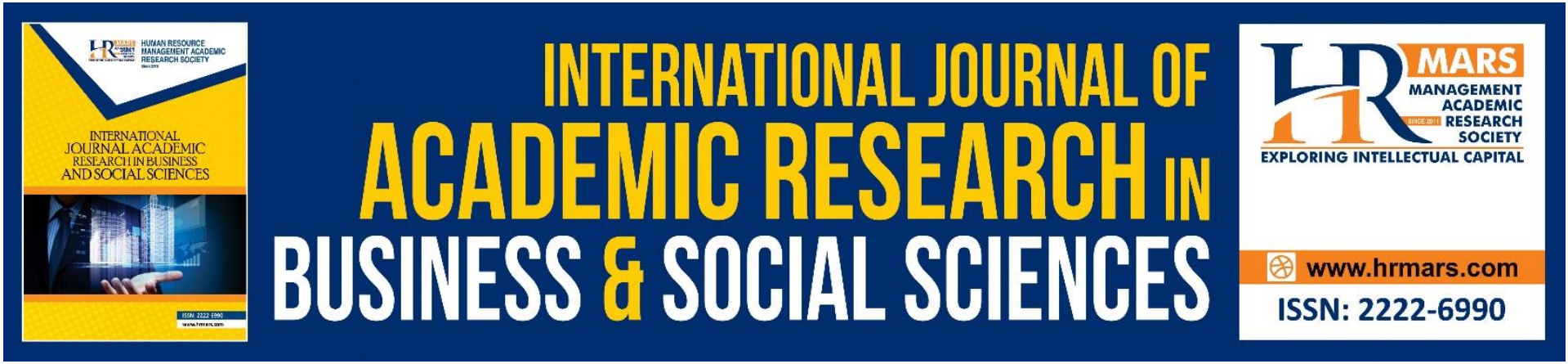

\title{
Layperson Representation in Alternative Dispute Resolution (ADR): A Legal Analysis
}

Su'aida Safei, Nuraisyah Chua Abdullah

To Link this Article: http://dx.doi.org/10.6007/IJARBSS/v11-i11/11260

DOI:10.6007/IJARBSS/v11-i11/11260

Received: 04 September 2021, Revised: 30 September 2021, Accepted: 19 October 2021

Published Online: 01 November 2021

In-Text Citation: (Safei \& Abdullah, 2021)

To Cite this Article: Safei, S., \& Abdullah, N. C. (2021). Layperson Representation in Alternative Dispute Resolution (ADR): A Legal Analysis. International Journal of Academic Research in Business and Social Sciences, 11(11), $91-104$.

Copyright: ( 2021 The Author(s)

Published by Human Resource Management Academic Research Society (www.hrmars.com)

This article is published under the Creative Commons Attribution (CC BY 4.0) license. Anyone may reproduce, distribute, translate and create derivative works of this article (for both commercial and non-commercial purposes), subject to full attribution to the original publication and authors. The full terms of this license may be seen at: $\underline{\text { http://creativecommons.org/licences/by/4.0/legalcode }}$

Vol. 11, No. 11, 2021, Pg. $91-104$

Full Terms \& Conditions of access and use can be found at http://hrmars.com/index.php/pages/detail/publication-ethics 


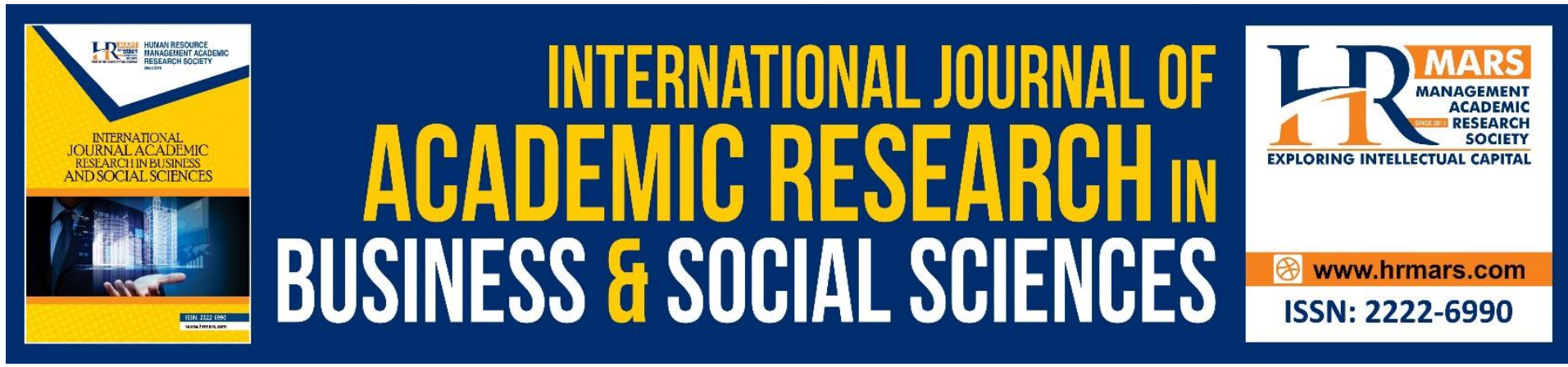

\title{
Layperson Representation in Alternative Dispute Resolution (ADR): A Legal Analysis
}

\author{
Su'aida Safei ${ }^{1}$, Nuraisyah Chua Abdullah (Prof. Dr) ${ }^{2}$ \\ 'Senior Lecturer, Faculty of Law, Universiti Teknologi MARA (UiTM), Shah Alam, Selangor, \\ Malaysia, ${ }^{2}$ Professor, Faculty of Law, Universiti Teknologi MARA (UiTM), Shah Alam, \\ Selangor, Malaysia \\ Email: suaidauitm@gmail.com
}

\begin{abstract}
The layperson representation supports the theory of legal pluralism. The essence is that not only the courts, as the official dispute mechanisms, are places for people to settle their disputes. There are various kinds of ADR outside the courts, as the unofficial dispute mechanisms, which provide alternative methods for parties to resolve their disputes. Using the qualitative approach, this paper serves as an overview of layperson representation in ADR from two perspectives, i.e., as ADR practitioners and as representatives of the disputing parties. The layperson representations are illustrated via the comparative approach of selected forums of dispute settlements in Malaysia and some foreign jurisdictions. The paper concludes that even though layperson representation is essential, it is clear from the discussion that the rigidity in applying layperson representation without the flexibility in getting legal representation whenever the needs arise is not an ideal perspective. The layperson representation concept in ADR should be used appropriately in consideration of serving better justice. It should not be an alternative to legal representation at the expense of ignoring technical legal issues that arise in disputes.
\end{abstract}

Keywords: Alternative Dispute Resolution, Layperson Representation

\section{Introduction}

Alternative Dispute Resolution (ADR) does not have a universally agreed-upon definition. To some, especially in the United States, the word encompasses all non-judicial dispute settlement procedures (and therefore includes arbitration). In the United Kingdom, $A D R$ is generally understood to refer to all dispute resolution methods other than court proceedings and arbitration, or just non-adjudicative dispute resolution methods like mediation, executive tribunal (essentially a more formal type of mediation, known in the United States as "mini-trial"), and early neutral evaluation, for example (Practical Law, 2021). In Australia, the definition of ADR seems to follow the definition in the United States where ADR refers to processes, other than judicial determination, in which an impartial person (an $A D R$ practitioner) assists those in a dispute to resolve the issues between them (Law Council of Australia, 2020). 
This paper serves as an overview of layperson representation in ADR in two perspectives: firstly, as an ADR practitioner and secondly, as a representative of the disputing parties. This paper discusses the main types of ADR, i.e., the statutory tribunals, conciliation and mediation. The paper examines the practices of some institutions in Malaysia and practices of selected foreign jurisdictions, i.e., Singapore, New Zealand and Australia. These three foreign countries are selected because they also practice the common law legal system, similar to Malaysia's common law legal system.

\section{Literature Review}

Some writers give different classifications to ADR. For example, Astor and Chinkin discussed different classifications of ADR processes, i.e., the primary ADR processes, the most commonly used ADR and the hybrid ADR processes, i.e., the combination of more than one ADR (Astor and Chinkin, 2002). Other writers categorise ADR according to the nature of its process. Sourdin, for example, categorised ADR into three: the facilitative processes, the advisory processes and the determinative processes (Sourdin, 2005).

Machura highlighted several benefits of participation of lay judges (Machura, 2016). Among others, the author states that lay judges are in line with the principle of democracy where it represents the people in the decision-making process in the courts. The author continues to state that lay judges serve as supplements to professional judges. In certain areas such as in specialised labour courts, they are representatives of employers and employees as members of the labour courts. Lay judges, according to him, allow a discussion with the professional judges and may lead to a more balanced conclusion.

Genn criticised that even though most tribunal hearings are more informal and procedurally more flexible than courts, such informality has been wrongly assumed to extend to all aspects of tribunal processes (Genn, 1993). He cautioned that informal procedures do not relieve tribunals from the obligation to make reasoned and consistent decisions, and hence, legal representation must be considered more realistically. Ivkovic cautioned that the challenge would be to rebut the argument that lay judges were more emotional and lenient, justifying the professional tribunals to be preferable (Ivkovic, 2007). The author illustrated them as being emotional, having a lower standard of proof and being too easily persuaded by professional judges.

Having layperson representation would mean that no legal representation is required. Cronin's article included recommendations for lowering civil litigation costs, among other things. She used the example of lawyers being barred from the Disputes Tribunal in New Zealand, where self-reliant men would settle their differences without the involvement of lawyers. (Cronin, 2019). Similarly, in Singapore, Gramckow and Ebeid talked about how the Small Claims Tribunal uses straightforward procedures that are easier for litigants to follow that eliminate the need for parties to be represented by lawyers (Gramckow and Ebeid, 2016).

In contrast, Amin and Abu Bakar disagreed with only allowing layperson representation in the Malaysian Tribunal for Consumer Claims (TCC). They proposed that the TCC be given some leeway in allowing an exception to the restriction on legal representation in certain circumstances. They used Australia, New Zealand, and India as examples. They also proposed an alternate solution, i.e., permitting parties to be represented by consumer associations. According to them, many legal persons in such associations and their members are eager to defend consumers' rights and best interests (Amin and Abu Bakar, 2010).

Another author, Safei, concurred with Amin and Abu Bakar and advocated amending sections 108(2) and 108(3) of the Consumer Protection Act 1999 (CPA) to reduce the risk of 
power imbalance, focusing on the parties' eloquence when presenting their case before the TCC. It was suggested that the TCC follow the practice of the Tribunal for Homebuyer Claims, as outlined in section $16 \mathrm{U}$ (2) of the Malaysian Housing Development (Control and Licensing) Act 1966, that allows for the representation of an advocate and solicitor if the President believes that the circumstances justifying it (Safei, 2010).

As for Australia, there is a lack of writings on the issue of layperson representation. The related discussion can be found in the legislations that will be elaborated on later in this paper. Given the lack of comprehensive discussion on layperson representation in ADR, this paper fills the gap.

\section{Related Theory}

The application of lay participation in ADR being the focus of this paper is very much related to the theory of legal pluralism. Legal pluralism started from the rejection of what Griffiths calls 'the ideology of legal centralism,' by which he means "law is and should be the law of the state, uniform for all persons, exclusive of all other law, and administered by a single set of state institutions" (Griffiths, 1986).

Santos proposed the concept of "legal hybrid" or "hybridisation," in which the official and unofficial components of the system are combined. Organisations created by law but whose operations are not regulated by law or are not part of the official legal system are examples (such as there is no appeal to the official courts from the decisions of the community courts). They are not considered part of the judicial system because they make decisions "with impartiality, good sense, and equity" rather than according to the law. They should, however, become organs of justice "for the purposes of reconciliation or the resolution of minor disputes" (de Sousa Santos, 2006).

In a later work of Moore in 2014, she evaluated the work of numerous authors who wrote on legal pluralism during the 1960s, including her own work in 1986 . She observed that describing the relationship between non-official norms and official systems is difficult. She stressed that this is because their interaction is not a set state of affairs. It is a gradual process that takes place over time. She stated that the official and unofficial "systems" are not fixed. She acknowledged that even though official law may appear stable, its content or practical execution can vary greatly over time. According to her, unofficial law can also undergo modifications. She concluded that the word "legal pluralism" as it is commonly used is a broad overview of a highly changeable process and it combines official forms of law with groups of unofficial rules. (Moore, 2014).

Faruqi elaborated on Malaysia's "legal pluralism," which can be seen in the existence of the ordinary court system that runs from the lowest court, the Magistrates' Court, to the highest court, the Federal Court. These courts are referred to as the "civil court" system. He stated that there are other dispute resolution mechanisms that exist in addition to these courts. According to him, each state has its own Syariah Courts for Islamic law and Malay adat, as defined in the Malaysian Federal Constitution's Ninth Schedule, List II, Paragraph 1. Native Courts enforce native laws in Sabah and Sarawak. He further stated that a Special Court exists under Articles 182 to 183 of the Malaysian Federal Constitution to hear cases brought by or against Malay rulers. He added that there are also statutory tribunals with names like the Industrial Court, Court Martial, Disciplinary Committees and Tribunals (Faruqi, 2015).

In essence, concerning the topic of this paper, the theory of "legal pluralism" can be simplified as follows. It is not only the courts as official adjudicators to settle disputes in society. They are other people outside the courts who do not have legal background, are 
involved in making decisions for the disputing parties (like arbitrators), or are involved in helping disputing parties make their own decision (like conciliators and mediators).

\section{Research Methodology}

This paper adopts a qualitative approach where content analysis is made on the Consumer Protection Act 1999 (CPA) and the related laws on ADR in courts, i.e., the Rules of Court 2012, Practice Direction on Mediation, the Practice Direction No.4 of 2016, Practice Direction on Mediation, and other relevant statutes and rules, i.e., the Housing Development (Control and Licensing) Act 1966, the Industrial Relations Act 1967, the Legal Profession Act 1976, the Law Reform (Marriage and Divorce) Act 1976, the Islamic Family Law (Federal Territories) Act 1984, the Islamic Family Law (State of Selangor) Enactment 2003, the Hakam (State of Selangor) Rules 2014 and the Asian International Arbitration Centre Mediation Rules 2018. Comparative study on the laws are made in the area of tribunals for consumers in Australia, in New Zealand and the practices of the Small Claims Tribunal in Singapore. Consequently, content analysis is made to the relevant laws in Australia, New Zealand and Singapore, i.e., the Queensland Civil and Administrative Tribunal Act 2009, the New South Wales Civil and Administrative Tribunal Act 2013 No 2 [NSW], the New South Wales Civil and Administrative Tribunal Rules 2014, the New Zealand's Disputes Tribunal Act 1988, the Small Claims Tribunals Act 1984 and the Small Claims Tribunals (Amendment) Act 2018. The laws governing court mediation in Malaysia, practices of the Industrial Court and the Disciplinary Board of the legal profession are also examined to represent the local practice of Malaysia that have lay participation in their systems.

\section{Finding and Discussion}

\section{Benefits of Lay Participation: A Re-Evaluation}

Lay judges are viewed as participants in the administration of justice, in accordance with the democratic principle, and as supplements to professional judges. Lay judges are viewed as individuals who can represent the people and provide a broader social spectrum of society because they can penetrate the self-employed, the ordinary worker, and the welfare recipient, illustrating a better legal system that is more accessible to the people. Although they lack legal knowledge, they can contribute effectively with knowledge, expertise, and experience in areas where professional judges lack knowledge. When combined with the legal judges, their decisions result in a more balanced decision (Machura, 2016).

Despite the fact that lay judges are preferred in certain dispute forums, as discussed in this paper, the challenge would be to refute the claim that lay judges are more emotional and lenient, thus justifying the use of professional tribunals (Ivkovic, 2007). They were accused of being emotional, having a lower standard of proof, and being too easily persuaded by professional judges because they lacked a legal background and training. Suppose professional judges are given the choice of whether or not to have lay judges participate in making legal decisions. In that case, this could lead to no lay participation, particularly if the professional judges dislike lay judges or are directly opposed to the system of lay participation.

Although most tribunal hearings are more informal and procedurally more flexible than courts, it has been suggested that this informality extends to all aspects of tribunal processes. The fact that hearings take place at a table and that an appellant can choose whether or not to present his case first are positive features that should be preserved and possibly expanded. The need for applicants to bring their cases within the regulations or 
statute, and prove their factual situation with evidence, cannot be overcome or altered by the procedural informality of tribunals. Informal procedures also do not exempt tribunals from making rational and consistent decisions. As a result, as discussed later in this paper, the need for mixed judges is justified.

The 'small is simple' fallacy conveniently supports some of the justifications for establishing tribunals in which ordinary people might present their own cases, but the weakness in the argument was exposed in the statements of those whose job it is to decide such cases. It has also been challenged by other evaluations of procedures in small claims courts and tribunals (Genn, 1993).

However, it is undeniable that prohibiting professionals/lawyers from representing parties would lower litigation costs and encourage consumer self-determination. This would prevent such professionals from exerting undue pressure on the weak consumers, lowering their sense of empowerment and self-confidence. As a result, the prohibition of professionals/lawyers will not affect how the case is presented to the readily strong and confident consumers. Cuts in legal aid, at least in the United Kingdom, have resulted in more people representing themselves, removing the protection of a legal-language expert (Wright, 2017). However, prohibiting legal representation may cause non-confident consumers to abandon their plans to file a complaint with the tribunal.

\section{Layperson Representation in Decision-making and/or ADR Practitioner in Selected ADR in Malaysia}

The first ADR to be considered is the statutory tribunals; examples here are the Disciplinary Board and the Industrial Court. In Malaysia, when there is a complaint against an advocate and solicitor (a lawyer) for alleged misconduct, the complaint shall be made to the Disciplinary Board, which is in charge of disciplinary actions against lawyers in Malaysia (sections 99(1) and 94(1) of the Legal Profession Act 1976). The Disciplinary Committee, which assists the Disciplinary Board, is the first example of layperson representation in ADR in Malaysia. The Disciplinary Committee's role is to assist the Disciplinary Board in conducting investigations and ultimately making recommendations on findings and punishment. The Disciplinary Committee's findings on whether a lawyer is guilty of misconduct are usually agreed upon and adopted as the Disciplinary Board's decision. Court of Appeal judgments in the cases of Iszam Kamal bin Ismail v. Prestij Bestari Sdn Bhd (Majlis Peguam Malaysia, Intervener) [2017] MLU 1034 and Ramasamy a/l Amaippan v. Kwan Lee Pin (Majlis Peguam Malaysia, Intervener) [2017] MLJU 783 are examples of such cases. Although the members of the Disciplinary Board are people with a legal background, the Disciplinary Committee has one lay member. Sections 103A (2)(b) and 96 (1) of the Legal Profession Act 1976 provide for a layperson to join the Disciplinary Committee alongside two senior lawyers with ten years of experience. The Disciplinary Committee is appointed from the Disciplinary Committee Panel, consisting of 30 members: 20 lawyers with at least 10 years experience and valid practising licences, and 10 lay persons (sections 96(1) and 103A(2) of the Legal Profession Act 1976). The Industrial Court is another example of ADR with layperson representation in Malaysia. The primary duty of the Industrial Court is to resolve trade disputes (Aminuddin, 2011). In addition to the President, the Industrial Court has two other members chosen by the President from each panel listed in section 21 (1) of the Industrial Relations Act 1967: employers and employees (sections 21(1)(a)(b), 22(1) of Industrial Relations Act 1967 and Yeoh et al., 2011). Thus, the Industrial Court has lay members. In addition, the President is aided by two or more Division Chairmen. The President of the Industrial Court and Chairman 
are senior lawyers with seven years' experience or members of the Federation's judicial and legal service (sections 23, 23A (1) of Industrial Relations Act 1967). The Industrial Relations Act of 1967 does not specify qualifications for members of both panels. After consulting the Malaysian Trades Union Congress (MTUC) and Malaysian Employers Federation (MEF), the President appoints the panels. These groups submit a list of potential panelists. The President can choose from these lists. The 3-panel members are then scheduled to appear in court. When a complaint of unfair dismissal is being heard, the President or Chairman can sit alone without a panel (Aminuddin, 2011). Therefore, it can be seen here that laypersons are also participating as members of the bench to decide trade disputes cases between employees and employers. Since these laypersons represent the employees and the employers whose names were proposed by organisations connected to employees and employers, they are experts in their area. Their expertise will help the President who is presiding the bench to provide views that are within their areas of expertise and which are not related to law. This would allow the President to decide and deliver a balanced decision/ award that considers the law and the factual considerations surrounding the case.

The second ADR to be considered is conciliation. Layperson representation can be found in the practice of conciliation in family disputes, both for Muslims and non-Muslims. For Muslims, the Islamic law is a State matter. Therefore, there are various State Enactments and one Act of Parliament for Federal Territories. Two samples of legislations will be taken, i.e., from the Islamic Family Law (Federal Territories) Act 1984 (IFLA) and the Islamic Family Law (State of Selangor) Enactment 2003 (Selangor Enactment). In the Federal Territories, section 47 (5) of IFLA provides for reference to the Conciliatory Committee when any one of the two grounds exist, i.e., firstly, the other party does not consent to the divorce, or it appears to the Syariah Court that there is a reasonable possibility of a reconciliation between the parties. The Conciliatory Committee consists of 3 people, firstly a Religious Officer as the Chairman. Secondly, the other two are laypersons, i.e., one person acts for the husband and the other acts for the wife. The Syariah Court, in appointing the said two laypersons, would give preference to the close relatives of the parties having knowledge of the circumstances of the case (sections $47(5)$ and $47(6)$ of IFLA). This is similarly provided verbatim in section 47 of the Selangor Enactment (sections 47(5) and 47(6) of the Selangor Enactment).

For non-Muslims, the practice of conciliation can be found in the sections in the Law Reform (Marriage and Divorce) Act 1976(LRA). It should be noted here LRA uses a different term of "reconciliation" compared to IFLA and Selangor Enactment, which refer to the process as "conciliation." Nevertheless, the two earlier-mentioned words will be treated the same for the purpose of this paper because the process and the outcome are the same, i.e., the process is to reunite divorcing couple and if the process is successful, then the outcome is also the same, i.e., it avoids divorce between parties. The ground for reference to the reconciliation in LRA is the same with one of the grounds to refer to conciliation in IFLA and Selangor Enactment, as stated in section 55(2) of LRA, i.e., when "there is a reasonable possibility of a reconciliation between the parties to the marriage," the High Court will adjourn the proceedings in court to give way to reconciliation. Section 55(1) of LRA provides for reconciliation by "such persons or bodies as may be made available for effecting a

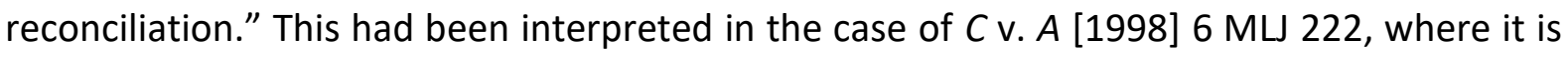
stated as "...to prevent injustice it is appropriate for this court to hold that attempts by relatives to reconcile the parties ought to be accepted and read together with section 55 and 
proviso (vi) to s 106 of the Act" (Hak, 2008). It is observed that there is a similarity between conciliation for Muslims and reconciliation for non-Muslims of where relatives as laypersons are involved in the process of ADR of reconciling divorcing couple from getting a divorce, hence saving their marriage. Relatives are regarded as among the closest people to the divorcing couple. Therefore, they may be better persons with better chances to persuade the couple to reconcile and resume their marital relationship.

There is another alternative forum for reconciliation for non-Muslims, which involves laypersons, a conciliatory council set up by section 106(3)(a) of LRA, "a council set up for the purposes of reconciliation by the appropriate authority of any religion, community, clan or association". Nonetheless, this conciliatory council has been criticised as unpopular because the couple may be hesitant to discuss their marital problems with members of religious organisations. Because religious councils are such close-knit groups, the couple may be embarrassed to "wash their dirty linen" in front of the community's righteous and upright members. The couple may be concerned that religious bodies and organisations are religious fundamentalists who will do everything possible to save their marriage (Sitravelu, 1983 and Hak, 2008).

For Muslims in Malaysia, other than conciliation, there is another ADR in settling family disputes that involve laypersons as the decision-makers, i.e., the practices of Majlis Tahkim and Hakam. A sample from Hakam (State of Selangor) Rules 2014 can be taken as an example. Rule 2 of Hakam (State of Selangor) Rules 2014 is the Rule containing the Interpretation of certain essential words used in the Rules. "Majlis Tahkim" is defined as the arbitration session or the process to resolve quarrels (shiqaq) involving a meeting between husband and wife, and the Hakam for the purpose of reconciliation or divorce by a pronouncement of talak or by khuluk. Hakam is defined as an arbitrator authorised by the parties or the Court to resolve quarrels (shiqaq) between husband and wife. "Shiqaq" is further defined as constant quarrels between husband and wife which affect the marital harmony. Therefore, in simpler words, "Majlis Tahkim" is the Islamic arbitration and Hakam is the Islamic arbitrator appointed when there is a dispute between the husband and the wife, which may give rise to a divorce either by talak or by khuluk. In Majlis Tahkim, the first category of Hakam consists of laypersons who are appointed by parties to the marriage (husband and wife) from among their respective close relatives when the Syariah Court is satisfied that there are constant shiqaq between them (Rule 3 (1) of Hakam (State of Selangor) Rules 2014). There are two functions of Hakam in Majlis Tahkim as stated in Rule 9 of Hakam (State of Selangor) Rules 2014, i.e., firstly they shall terminate the shiqaq between the husband and wife by way of reconciliation or secondly, they shall separate both parties by choosing any one of the two types of divorce in Islam: either by talak or khuluk. It is observed that the first function of Hakam is similar to the practices of the Conciliatory Committee in IFLA and Selangor Enactment, as stated earlier, to the extent of reconciling parties and avoid divorce from occurring. It is also a similar practice of the conciliatory councils as stated in the LRA. Whereas, for the second function of Hakam in separating parties through a divorce, that is not within the power of the Conciliatory Committee or the conciliatory councils to do so and only the Syariah Court for Muslims and the High Court for non-Muslims that have the power to order a divorce. Nevertheless, the Hakam is empowered by the Syariah Court in executing the second function, which is clearly stated in Rule 10 (a) of Hakam (State of Selangor) Rules 2014, i.e., "during the conduct of Majlis Tahkim, Hakam shall accept and perform directions of the Court from time to time." Consequently, it is evident through the practice of Hakam and Majlis Tahkim that the Syariah Court acknowledges the significant role 
of laypersons as decision-makers that the Syariah Court can delegate its power of divorcing parties to the two laypersons Hakams in Majlis Tahkim.

The layperson representation in ADR can further be observed in the practice of courtannexed mediation in Malaysian courts. There are two categories of mediators stated in the Practice Direction No. 4 of 2016 Practice Direction on Mediation, issued by the Chief Registrar of the Federal Court of Malaysia (PD 2016) on June 30, 2016, i.e., the judge-led mediators and the non-judge-led mediators. This PD2016 is being issued to provide additional explanations on the pre-trial case management process outlined in Order 34 rule 2(2)(a) of the Rules of Court 2012, which mentions mediation in conformity with the current practice direction. According to the PD 2016, the non-judge-led mediators can be further divided into two subcategories, i.e., the mediators from the Malaysian Mediation Centre (MMC), who are lawyers and the mediators with the Asian International Arbitration Centre (AIAC) who can be people with no legal background (Chief Registrar, Federal Court of Malaysia, 2016). For the purpose of this paper, the second category of the non-judge-led mediators who are AIAC mediators is considered laypersons because they do not have qualifications related to law. To apply as a mediator with the AIAC, one must fulfill specific requirements that having a legal background is not one of them (AIAC, 2021). Although AIAC mediators do not decide for parties, they still have an essential role in settling disputes between parties, i.e., they facilitate negotiation between parties to help them reach a mutually acceptable solution.

\section{Layperson Representation in Decision Making and/or ADR Practitioner in Selected Foreign Jurisdictions}

In Australia, lay representation in decision-making can be seen in the membership of non-legal members of the tribunal who make decisions over some issues brought before them. Examples can be seen in the practices of the Queensland Civil and Administrative Tribunal (QCAT) and the New South Wales Civil and Administrative Tribunal (NSWCAT). In QCAT, the senior members and the ordinary members can be appointed among people with extensive knowledge, expertise or experience relating to a class of matter for which the Tribunal may exercise functions. These people are laypersons with no legal background (Section 183 (3)(b) and Section 183 (4)(b) of Queensland Civil and Administrative Tribunal Act 2009). Similar to QCAT, NSWCAT also has laypersons in its composition of members. They are appointed from among those with special knowledge, skill, or expertise concerning matters within the jurisdiction of the NSWCAT (section 13 (4)(b), section 13 (5)(b) and section 13 (6)(a) of New South Wales Civil and Administrative Tribunal Act 2013 No 2 [NSW]).

Similarly, in New Zealand's Disputes Tribunal (NZDT), the lay representation in ADR can be seen in the qualification of its Referees. In NZDT, the Principal Disputes Referee to be appointed must hold a Bachelor of Laws from a New Zealand university or a qualification that the Minister of Justice considers equivalent to such Bachelor of Laws and must be a person with the attributes, knowledge, and experience to perform the functions of a Principal Disputes Referee and a Referee (Section 6A(2) of the Disputes Tribunal Act of 1988). However, there is no legal qualification required for the other members of the NZDT (referred to as Referees). Under Section 8 of the Disputes Tribunal Act 1988, the Referees are required to be persons with the necessary attributes, expertise, and experience to perform the Referees' tasks and be successfully selected by an evaluation panel (Sections 7(2)(a) and 8(1)(b) of the Disputes Tribunal Act 1988).

In Singapore, lay representation in ADR can be seen in the Small Claims Tribunal (SSCT), with assessors assisting the Tribunal member. Before the 2018 amendments to the 
Small Claims Tribunal Act, a member of the Tribunal was referred to as a "Referee." Following the amendments in 2018, the term "Referee" was removed and replaced with "Tribunal Magistrate." (Government Gazette Acts Supplement, Republic of Singapore, 2018). The Tribunal Magistrate has a legal background. The Presiding Judge of the State Courts may appoint a District Judge or a Magistrate as a Tribunal magistrate, according to Section 4 of the Small Claims Tribunal (Amendment) Act 2018. Furthermore, on the recommendation of the Chief Justice, the President may appoint a qualified person as defined in the Legal Profession Act to serve as a tribunal magistrate (Section 4 of the Small Claims Tribunal (Amendment) Act of 2018).

However, the amended section 24 of the Small Claims Tribunal (Amendment) Act 2018 allows people with skills and experience to serve on the SSCT's panel as assessors. This can happen either on the SSCT's own initiative or at the request of any party to the proceedings (Section 24 (2) (b), Small Claims Tribunals (Amendment) Act 2018). This is viewed favourably because it allows people with non-legal backgrounds to assist the SSCT in making its decision. As previously discussed, Australia and New Zealand are more advanced than Singapore, where people with skills and experience serve as members of the Tribunal and make decisions for disputing parties before them. It is believed that including lay people with expertise, knowledge, and experience in the decision-making process in ADR would provide a more common sense in better understanding of parties appearing before them, who are general members of the public.

It is observed that at the QCAT, NSWCAT, NZDT, and SSCT, there is a mix of legal and non-legal members. Those who do not have a legal qualification are expected to have special knowledge, experience, or expertise in the area under the jurisdiction of these Tribunals. The fact that ADR processes available in these tribunals do not require legal expertise but more expertise in the disputed area to help amicably resolve them influences the requirements for expertise or experience.

\section{Layperson Representation on Behalf of Disputing Parties in Malaysia}

Legal representation is prohibited in some ADRs in Malaysia, which indirectly supports layperson representation. A few examples demonstrate this. The first is the statutory tribunal, the TCC, where section 108(2) of the Consumer Protection Act 1999 (CPA) clearly states that no party shall be represented at a hearing by an advocate and solicitor. This ban on legal representation at the TCC clearly supports layperson representation by the parties themselves. Representation by others at the TCC is limited to a full-time paid employee of a corporation or an unincorporated body of persons and by next friend or guardian ad litem of a minor or a person under disability (Section 108(3) of the Consumer Protection Act 1999). Representation by family members of a consumer (claimant) is only allowed with the leave of the President. The current practice is to allow representation only if the consumer (claimant) cannot communicate in English or Malay in line with the discretion given to the TCC.

Conciliation in family disputes is the second ADR that supports layperson representation for Muslims. In conciliation for Muslim family disputes, a sample can be taken from the IFLA, where section 47(12) states that no Peguam Syarie (a lawyer for Syariah law matters) shall appear or act for any party before a conciliatory committee, and no party shall be represented by anyone other than a member of his or her family without the permission of the conciliatory committee. Section $47(12)$ of the Selangor Enactment also provides for this. 
Similar to conciliation, sections 48 (7) of both the IFLA and the Selangor Enactment prohibit Peguam Syarie from attending Majlis Tahkim or representing any of the parties in the presence of the Hakam. It is also provided in the same sections of the two legislations that a close member of the parties' family can be present or represent any of the parties in Majlis Tahkim before the Hakam.

For family disputes of non-Muslims in Malaysia, a similar practice of prohibiting an advocate and solicitor from appearing before the conciliatory body and allowing a member of the disputing parties' family to represent them with the conciliatory body's permission can be found in Section 106 (5) (c) of the LRA.

\section{Layperson Representation on Behalf of Disputing Parties in Selected Foreign Jurisdictions}

As previously stated in this paper, the ADRs from selected foreign jurisdictions covered in this paper are the QCAT, the NSWCAT, the NZDT, and the SSCT. The QCAT may allow a party to be represented by a person who has authority to settle the dispute concerning the matter in the proceeding for the party in three ADRs: conciliation, compulsory conference, and mediation (Sections 66B(1), 68(1), and 76(1) of the Queensland Civil and Administrative Tribunal Act 2009), who do not necessarily have a legal background. People with no legal backgrounds can also be appointed as representatives at NSWCAT, similar to QCAT, with leave or permission from the NSWCAT. They must meet the following criteria: sufficient knowledge of the issues in dispute, the ability to deal fairly and honestly with the NSWCAT and others involved in the proceedings, sufficient authority to bind the party, and any other circumstances deemed relevant by the NSWCAT (Section 45(1)(a)(b)(i) of the New South Wales Civil and Administrative Tribunal Act 2013 No 2 and Rules 32(1)(a)(i)(ii)(iii), 32(1)(b) of the New South Wales Civil and Administrative Tribunal Rules 2014).

On the other hand, there is a list of people at the NZDT who the NZDT may approve to appoint a representative to act on behalf of the disputing parties in the NZDT proceedings. The Crown can be represented by an officer or employee of the Crown, a corporation or an unincorporated body of persons can be represented by an officer or employee or a member of a corporation or a body or holds directly or indirectly, at least a $50 \%$ interest in it, and a person jointly liable or entitled with another or others can be represented by one of the persons jointly liable or entitled or in the case of a partnership, an employee of the partnership can represent it (Disputes Tribunal Act 1988, Section 38 (3)(a)(b)(c)). These individuals may not have a legal background. The list is not exhaustive, and the NZDT may authorise any other person to represent a party in its proceedings if it is satisfied that "for sufficient cause, that person is unable to appear in person or is unable to present his or her case adequately" (Disputes Tribunal Act 1988, Section 38 (3)(e)). The disputing party may also nominate any person to be present at the hearing and assist in presenting their case if the NZDT considers it appropriate in all the circumstances to do so and approves such person (Disputes Tribunal Act 1988, Section 38 (5)). Before NZDT approves a representative, it must be satisfied that the proposed representative has sufficient knowledge of the case and authority to bind the party (Section 38 (4) of the Disputes Tribunal Act of 1988).

In general, each party to the proceedings at the SSCT must present their own case (Section 23 (1) of the Small Claims Tribunal Act of 1984). The SSCT, like the NZDT, has a list of people who can represent a party to the proceedings. They are a public officer of the Government, a full-time employee of the Town Council under the Town Councils Act or its management agent, an officer or a full-time employee of a body corporate, a partner or a full- 
time employee of a partnership, a member of an unincorporated association or its full-time employee, a member of the council to a management corporation under the Land Titles (Strata) Act, a member of the council to a management corporation under the Land Title (Section $23(2)(a)(b)(c)(d)(d a)(e)(f)(g)(h)(i)$ of the Small Claims Tribunal Act 1984). Like the NZDT, before the SSCT approves any person to be a representative, it must be satisfied that the person has sufficient knowledge of the case and authority to bind the party he represents (Section 23 (4) of the (Small Claims Tribunal Act, 1984).

The Community Justice and Tribunals Division ("CJTD") Friend Scheme was implemented by Singapore's State Courts on May 1, 2019. Unrepresented litigants-in-person who are parties to the proceedings may apply to the Tribunal for a family member, friend, or volunteer from the Community Justice Centre or a pro bono agency to assist that party at the proceedings by taking notes or explaining the proceedings in a language that they understand, or for emotional and moral support (States Courts, Singapore, 2020), (States Courts, Singapore, 2019, April 24). This is also applicable to SSCT because it is part of the Singapore's States Court, where the SSCT may allow one or more individuals to attend and assist a party in the proceedings on the parties' application (States Courts, Singapore, 2020).

\section{Recommendations and Conclusion}

It is proposed that in conflict resolution forums where non-legal decision-makers are unavailable, such as the TCC, people with skills and competence in the area of dispute should sit on the bench with the President (who has a legal background), establishing 'mixed presidents.' This will assist the President in areas where he or she lacks knowledge. These individuals are known as "lay presidents or co-presidents." They are not needed to be permanently affiliated with the TCC, but they may be called when their services are required. Cases requiring the aid of lay presidents may be bundled and heard in a single session within one to two days of the hearing. The number of lay presidents or co-presidents will be determined on a case-to-case basis.

As previously noted, the restriction of a legal representative in some forums, such as the TCC, can lead to power imbalances, particularly in terms of the parties' eloquence while presenting their case before the TCC when an employee with a legal background represents the defendant. The TCC should adopt the practice of the Tribunal for Homebuyer Claims, as provided in section $16 \mathrm{U}$ (2) of the Malaysian Housing Development (Control and Licensing) Act 1966, which allows for the representation of an advocate and solicitor if the President feels the circumstances justifying it. Allowing parties to be represented by consumer associations is an alternative because many legal persons in such associations and their members are eager to defend consumers' rights and best interests. Even in a quick and straightforward dispute resolution venue like the TCC, this would address lay participation's limitations, as legal discussions are unavoidable in such settings.

In addition, the impact will be worst for the disputing parties with the acceptable norm in ADR that ADR practitioners are not allowed to give legal advice to them. Therefore, it is recommended that the legislation or the subsidiary legislation clearly provide for exceptional circumstances in which legal representation may be allowed. An example of such exceptional circumstances is when there are issues of law involved in the case which would prejudice parties' interests if legal representation is not allowed.

It is clear from the discussion that rigidity in applying layperson representation without the flexibility in getting legal representation whenever the needs arise is not an ideal perspective. The layperson representation concept in ADR should be used appropriately in 
consideration of serving better justice. It should not be an alternative to the option of legal representation at the expense of ignoring technical legal issues that arise in disputes. A balanced application of layperson representation is in line with the theory of legal pluralism. The essence is that there are many official dispute mechanisms apart from courts that are available for people to settle their disputes.

As for the layperson representation in decision-making, which creates a mix of layperson judges and legal judges, this practice has advantages and disadvantages. One of the advantages is that by having the involvement of laypersons, it reflects democratic principle. In contrast, one of the disadvantages is that the views of the layperson judge may be ignored by the legal judge if there is no clear guideline as to their roles and contributions respectively towards the decision-making in ADR. A possible example of the guideline is that the legal judge shall take the views of the layperson judge in his area of expertise in concluding his decision. The legal judge should be mandated to justify his decision as to how he considered the layperson judge's views in reaching his decision. Likewise, the legal judge should also be mandated to state in the reasoning of his decision as to why he rejects the views of the layperson judge. This recommended practice would help ensure that the legal judge considers the expert views of the layperson in his decision, which serves the purpose of having a mixed layperson judge and legal judge in the process of decision-making in ADR.

\section{References}

Amin, N., \& Abu Bakar, E. (2010). ADR for consumers: An appraisal of the tribunal for consumer claims in Malaysia in Jan, M. N. I., Mohamed, A. A. A., \& Ali, A. (2010). Mediation in Malaysia: The Law and Practice, Selangor: LexisNexis at pp.175-176.

Aminuddin, M. (2011). Malaysian Industrial Relations Employment Law (7 $7^{\text {th }}$ ed.). McGraw-Hill (Malaysia) Sdn Bhd, at pp. 208, 238.

Asian International Arbitration Centre. (2021). Become A Panellist. https://www.aiac.world/Become-A-Panellist-/B

Asian International Arbitration Centre. (2018). Mediation Rules. https://www.aiac.world/wpcontent/mediation-rules/AIAC-Mediation-Rules-2018.pdf

Astor, H., \& Chinkin, C. (2002) Dispute Resolution in Australia. (2nd.ed.) Lexis Nexis Butterworths., Chapter 3, pp.82 to 95.

Chief Registrar, Federal Court of Malaysia. (2016). Practice Direction No. 4 of 2016 Practice Direction on Mediation Consumer Protection Act 1999

Cronin, B. T. [2019]. Explaining and changing the price of litigation services, New Zealand Law Journal, pp. 310-319, at p. 318.

de Sousa Santos, B. (2006). The heterogeneous state and legal pluralism in Mozambique. Law \& Society Review, 40(1), 39-76, at pp. 41, 46, 47, 54, 55, 56, 57, 58.

Faruqi, S. S. (2015). The power of different courts, The Star newspaper. https://www.malaysianbar.org.my/article/news/legal-and-general-news/legalnews/the-power-of-different-courts

Genn, H. (1993). Tribunals and Informal Justice, The Modern Law Review Limited. pp.393-411, https://onlinelibrary.wiley.com/doi/pdf/10.1111/j.1468-2230.1993.tb02680.x

Hak, N. A. (2008). Reconciliation Provision under English and Malaysian Family Law: A Comparative Overview. The Law Review 2008, pp.104-118, at p.114

http://irep.iium.edu.my/6479/1/Reconciliation_The_Law_Review.pdf

Ivkovic, S. K. (2007). Exploring Lay Participation in Legal Decision-Making: Lessons from Mixed

Tribunals. Cornell International Law Journal. Vol.4: Iss.2, Article 4, 429-451 
Law Council of Australia. (2020). Alternative Dispute Resolution.

https://www.lawcouncil.asn.au/policy-agenda/access-to-justice/alternative-disputeresolution

Gramckow, H., \& Ebeid, O. (2016). Establishing small claims courts and the impact on service delivery in the justice system. Just Development Issue 9. http://documents.worldbank.org/curated/en/363681467994719303/pdf/104145-BRIPUBLIC-SERIES-JUST-DEVELOPMENT-21-3-2016-23-32-58-Just-Development-NoteFebruary2016-Issue9.pdf,.

Griffiths, J. (1986). What is legal pluralism? The Journal of Legal Pluralism and Unofficial Law, 18(24), 1-55, at p. 3. https://heinonline.org/HOL/Licence.

Machura, S. (2016). Civil Justice : Lay Judges in the EU countries. OñatiSocio-legal series [online] 6(2) 235-254. http:ssrn.com/abstract=2665612

Moore, S. F. (2014). Legal Pluralism as Omnium Gatherum. FIU L. Rev., 10, 5. at p. 18. https://ecollections.law.fiu.edu/lawreview/vol10/iss1/.

Practical Law. (2021). Glossary Alternative dispute resolution (ADR). https://uk.practicallaw.thomsonreuters.com/

Republic of Singapore Government Gazette Acts Supplement. (2018) Small Claims Tribunals (Amendment) Act $2018 . \quad$ https://sso.agc.gov.sg/Acts-Supp/332018/Published/20180810?DocDate=20180810.

Safei, S. (2010). Tribunal For Consumer Claims - An Alternative Method of Dispute Settlement for Consumers in Malaysia. Paper presented at Prosiding Seminar Kebangsaan MACFEA ke 14, Halatuju Penyelidikan Kepenggunaan. [14th National Seminar Proceeding MACFEA, Future Direction of Research in Consumerism : Issues and Challenges]. Equatorial Hotel Bangi, Bandar Baru Bangi, Selangor, Malaysia.

Sitravelu, M. N. (1983). "Conciliatory Bodies in Klang and Petaling Jaya", Academic Exercise, Faculty of Law, University of Malaya, Kuala Lumpur Small Claims Tribunals Act 1984

States Courts, Singapore. (2020). A Guide to SCT https://www.statecourts.gov.sg/cws/SmallClaims/Documents/AGuideToSCTBrochure_ 06042020(ed).pdf, at p. 16.

States Courts, Singapore. (2019). Practice Directions Amendment No.4 of 2019.https://www.statecourts.gov.sg/cws/Resources/Documents/PD\%204\%20of\%20 2019.pdf?fbclid=IwAR2DrxT7zJaU5LB0-aefpplz25cW1NXO-yPEb4jrZbdsRWuoiEpILcUQKs.

Sourdin, T. (2005) Alternative Dispute Resolution (2nd.ed.) Lawbook Co., at pp.17-39.

Wright, D. (2017). The Conversation, Language puts ordinary people at a disadvantage in the criminal justice system, https://phys.org/news/2017-08-language-ordinary-peopledisadvantage-criminal.html

Yeoh, A. L., Ismail, M. C. T., Mohamed, K., \& Bidin, A. (2011). Employment and Industrial law. Pearson Prentice Hall, at p.8. 